Jurnal Indonesia Sosial Teknologi: p-ISSN: 2723 - 6609

e-ISSN : 2745-5254

Vol. 2, No. 5 Mei 2021

\title{
EFEKTIVITAS PROGRAM PELAYANAN KESEJAHTERAAN SOSIAL ANAK JALANAN DI UPTD KAMPUNG ANAK NEGERI KOTA SURABAYA
}

\author{
Biru Bara Nirvana Cahyadhi, Nira Zhafirah Puspitasari, Dewi Austine Britania \\ dan Kalvin Edo Wahyudi
}

Program Studi Administrasi Publik, UPN Veteran Jawa Timur, Indonesia

Email: birunirvana19@gmail.com, Nirazhafirah12@gmail.com, dewi.austine@gmail.com, kalvinedo.adne@upnjatim.ac.id.

\section{Abstract}

The phenomenon of street children in the city of Surabaya is a problem that has not been resolved until now. One of the difficulties in alleviating street children in the city of Surabaya is due to the fluctuating errors every year. Various policies have been taken by the Surabaya City Government to alleviate the problem of street children. The Surabaya City Government through the Surabaya City Social Service took steps to resolve the problem of street children by forming the Regional Technical Implementation Unit (UPTD) of the Wonorejo State Children Village. This study aims to see the effectiveness of the social welfare service program for street children in the UPTD Kampung Anak Negeri and the factors that influence it. This program takes place in Rungkut Village, Surabaya by using a descriptive method with a qualitative approach. Data collection was carried out by observation, in-depth interviews with informants, and documentation study. The data analysis technique used an interactive model with the validity test technique through triangulation. The results showed that the street children welfare service program had not been implemented effectively because of the low awareness, motivation, and desire of the street children themselves. This ineffective implementation results in the less than optimal growth and development of street children as participants in the social welfare service program.

Keyword: program; effectiveness; street children.

\section{Abstrak}

Fenomena anak jalanan di kota Surabaya merupakan masalah yang sampai saat ini belum terselesaikan. Salah satu kesulitan dalam penanggulangan anak jalanan di Kota Surabaya adalah karena kesalahan yang selalu berfluktuasi setiap tahunnya. Berbagai kebijakan telah diambil oleh Pemerintah Kota Surabaya untuk mengatasi masalah anak jalanan. Pemerintah Kota Surabaya melalui Dinas Sosial Kota Surabaya mengambil langkah untuk mengatasi masalah anak jalanan dengan membentuk Unit Pelaksana Teknis Daerah (UPTD) Desa Anak Negeri Wonorejo. Penelitian ini bertujuan untuk melihat efektivitas program pelayanan kesejahteraan sosial anak jalanan di UPTD Kampung Anak Negeri dan faktor-faktor yang mempengaruhinya. Program ini berlangsung di Desa Rungkut, Surabaya dengan menggunakan metode deskriptif dengan pendekatan kualitatif. Pengumpulan data dilakukan dengan observasi, wawancara mendalam dengan informan, dan studi 
dokumentasi. Teknik analisis data menggunakan model interaktif dengan teknik uji validitas melalui triangulasi. Hasil penelitian menunjukkan bahwa program pelayanan kesejahteraan anak jalanan belum terlaksana secara efektif karena rendahnya kesadaran, motivasi, dan keinginan dari anak jalanan itu sendiri. Implementasi yang tidak efektif tersebut mengakibatkan tumbuh kembang anak jalanan yang kurang optimal sebagai peserta program pelayanan kesejahteraan sosial.

Kata kunci: program; efektifitas; anak jalanan.

\section{Pendahuluan}

Keberhasilan suatu daerah dalam hal pembangunan ditentukan oleh kebijakan dari aparatur pemerintah dalam merumuskan program kepada masyarakat. Ketimpangan pembangunan yang terjadi bahkan di daerah berbeda juga dapat menimbulkan konsekuensi tersendiri bagi daerah lainnya. Pembangunan yang hanya terpusat di suatu daerah dapat menimbulkan tingginya arus urbanisasi yang pada akhirnya menciptakan masalah-masalah baru pada daerah yang menjadi tujuan urbanisasi. Urbanisasi yang terlau berlebih mampu meningkatkan penambahan jumlah Penyandang Masalah Kesejahteraan Sosial (PMKS). Pada sisi lain, cepatnya arus pembangunan di suatu daerah tidak berjalan beriringan dengan meningkatnya kualitas kesejahteraan dari masyarakat.

Hingga tahun 2019, data dari Dinas Sosial Provinsi Jawa Timur mengungkapkan bahwa jumlah PMKS di Jawa Timur mencapai 600 ribu jiwa. Jumlah tersebut terdiri dari anak terlantar berjumlah 118 ribu jiwa, lanjut usia terlantar sebanyak 173 ribu jiwa, anak disabilitas 23,5 ribu jiwa, dan anak jalanan 1,9 ribu jiwa (Dinas Sosial Jawa Timur, 2019). Dari data yang diungkap oleh Dinas Sosial Jawa Timur tersebut, tidak hanya orang dewasa, anak-anak dapat tergolong pula sebagai PMKS. Permasalahan penigkatan jumlah anak jalanan nyaris dialami oleh seluruh daerah di Indonesia. Terlebih, ketika Indonesia dilanda krisis pada tahun 1997 yang mengakibatkan lonjakan tajam jumlah anak jalanan. Di Surabaya sendiri selaku salah satu pusat ekonomi di Indonesia bagian Timur, Dinas Sosial Kota Surabaya memperkirakan jumlah anak jalanan bertambah sebesar 30\% setahun setelah krisis 1997. Bahkan, pada tahun 2007 Departemen Sosial Republik Indonesia mengungkapkan bahwa Jawa Timur merupakan wilayah provinsi dengan jumlah anak jalanan terbanyak di Indonesia dengan jumlah 13.236 jiwa. Jumlah ini mencapai $24,4 \%$ dari total anak jalanan yang ada di Indonesia (R. F. S. Sari, 2015).

Surabaya sendiri, meskipun menduduki predikat sebagai ibukota Jawa Timur dengan wilayah terbesar kedua di Indonesia setelah Jakarta serta meraih banyak penghargaan dari instansi dalam maupun luar negeri. Tampaknya kemajuan pembangunan serta berbagai penghargaan yang diraih belum mampu mengentaskan secara menyeluruh permasalahan terkait anak jalanan yang ada di kota tersebut. Terlebih, fenomena anak jalanan dapat ditemui di banyak titik lokasi yang ada di Kota 
Surabaya seperti perempatan jalan raya, terminal bus, jalan-jalan protokoler, bahkan mereka sering berlalu lalang di café-café di pusat Kota Surabaya.

Meskipun anak jalanan di Surabaya seringkali dan mudah dijumpai, tetapi jumlah mereka terbilang fluktuatif atau naik-turun. Dari data yang dirilis oleh Dinas Sosial Kota Surabaya antara tahun 2009 hingga 2013, jumlah anak jalanan pada 2009 berjumlah 285 anak, pada tahu 2010 berjumlah 80 anak, pada tahun 2011 berjumlah 45 anak, pada tahun 2012 berjumlah 114 anak, dan pada tahun 2013 berjumlah 94 anak. Jumlah anak jalanan yang berhasil di data oleh Dinas Sosial Kota Surabaya seakan jauh dari apa yang dapat ditemui di lapangan hingga saat ini. Surabaya belum memiliki data yang mencatat seluruh anak jalanan yang terdapat di kota tersebut.

Dalam Undang-Undang Nomor 35 Tahun 2014 hasil dari revisi Undang-Undang Nomor 23 Tahun 2002 tentang Perlindungan Anak, diantaranya terdapat dalam pasal 22, 24, 25, dan 26, yaitu; negara dan pemerintah berkewajiban dan bertanggung jawab memberikan dukungan sarana dan prasarana dalam penyelenggaraan perlindungan anak; negara dan pemerintah menjamin anak untuk mempergunakan haknya dalam meyampaikan pendapat sesuai dengan usia dan tingkat kecerdasan anak; kewajiban dan tanggung jawab masyarakat terhadap perlindungan anak dilaksanakan melalui kegiatan peran masyarakat dalam penyelenggaraan perlindungan anak. Dengan kata lain, diperlukan adanya program pemberdayaan anak jalanan baik dari pemerintah, LSM, masyarakat, akademisi, maupun instansi lain baik swasta maupun negeri (D. P. Sari \& Sumarti, 2017).

Pada penanganan serta inisiasi program pemberdayaan anak jalanan di Kota Surabaya sesuai dengan amanat Undang-Undang Nomor 35 Tahun 2014, Pemerintah Kota Surabaya melalui Dinas Sosial Kota Surabaya telah jauh hari membentuk suatu wadah khusus untuk menampung anak yang memiliki masalah sosial yang dinamai UPTD Kampung Anak Negeri. UPTD ini oleh Dinas Sosial Kota Surabaya dibentuk pada 4 Januari 2009 berdasarkan Perwali No. 61 Tahun 2012 tentang Organisasi Unit Pelaksana Teknis Dinas Kampung Anak Negeri pada Dinas Sosial Kota Surabaya.

UPTD Kampung Anak Negeri sendiri merupakan suatu lembaga Unit Pelaksana Teknis Daerah pada Dinas Sosial Kota Surabaya yang mempunyai tanggung jawab memberikan pelayanan sosial kepada anak-anak nakal, jalanan, dan anak terlantar di Kota Surabaya dimana pelayanan yang diberikan dapat memberikan manfaat, keterampilan, keuntungan, dan bakat kepada mereka sehingga mampu melakukan fungsi sosial mereka kepada masyarakat.

Melihat dari latar belakang yang telah dipaparkan di atas, peneliti memiliki ketertarikan untuk meneliti serta menggali terkait Efektivitas Program Pelayanan Kesejahteraan Sosial Anak Jalanan di UPTD Kampung Anak Negeri Kota Surabaya. Penelitian akan dilakukan di UPTD Kampung Anak Negeri itu sendiri sebagai tempat yang mewadahi program pelayanan kesejahteraan sosial anak jalanan tersebut. Peneliti memilih topik penelitian ini karena melihat permasalahan anak jalanan yang tidak kunjung selesai terutama di Kota Surabaya. Padahal, pembangunan di Kota Surabaya 
telah mengalami kemajuan yang cukup pesat, hal ini dibuktikan dengan berbagai penghargaan yang didapatkan oleh pemerintah Kota Surabaya dalam beberapa tahun terakhir.

(Hasanah \& Putri, 2019). Efektivitas Program Penanggulangan Anak Jalanan Berbasis Community Development di Kota Serang (Studi Pada Program Rumah Singgah).

Penelitian ini menggunakan pendekatan kualitatif dengan metode deskriptif dan menggunakan teori efektivitas Duncan yang terdiri dari 3 (tiga) indikator yaitu pencapaian tujuan, integrasi, dan adaptasi. Hasil dari penelitian ini menunjukkan bahwa penanggulangan anak berbasis community development pada rumah singgah tidak berjalan efektif. Perbedaan penelitian terletak pada teori yang digunakan. Di sisi lain, pada penelitian ini hasil penelitian belum seluruhnya dijelaskan dengan teori yang digunakan.

Menurut (R. F. S. Sari, 2015). Studi Deskriptif tentang Efektivitas Pemberdayaan dalam Meningkatan Kemandirian Anak Jalanan di Unit Pelaksana Teknis Dinas (UPTD) Kampung Anak Negeri Dinas Sosial Kota Surabaya yang menggunakan tipe penelitian deskriptif kualitatif dengan teori dari James L. Gibson yang memiliki 7 (tujuh) kriteria keefektifan. Penelitian ini juga menggunakan pendekatan proses untuk melihat seberapa jauh ektivitas pelaksanaan program dapat dikatakan efektif. Hasil penelitian menyatakan bahwa pelaksanaan program belum berjalan efektif karena banyak target yang belum terlaksana dengan baik. Gap penelitian terletak pada tidak adanya penjelasan mengenai faktor-faktor apa saja yang turut mempengaruhi ketidakefektifan pelaksanaan program pemberdayaan di UPTD Kampung Anak Negeri Kota Surabaya.

Selanjutnya menurut (D. P. Sari \& Sumarti, 2017) Analisis Efektivitas Program Pemberdayaan Anak Jalanan di Rumah Singgah Tabayun Kecamatan Cibinong, Kabupaten Bogor yang menggunakan metode penelitian kuantitatif dengan survei terhadap 30 responden peserta program di Rumah Singgah Tabayun. Teori yang digunakan adalah teori efektivitas dari Budiani dengan 4 (empat) variabel efektivitas program. Hasil penelitian menunjukkan bahwa karakteristik peserta program seperti usia, jenis pekerjaan, dan jam kerja memiliki hubungan dengan tingkat efektivitas program. Penelitian juga menunjukkan bahwa tingkat efektivitas program Rumah Singgah Tabayun masih rendah. Perbedaan penelitian terdapat pada teori serta metode penelitian yang digunakan. Selain itu, variabel atau indikator penelitian yang digunakan untuk mengukur efektivitas juga memiliki perbedaan.

Efektivitas menurut (Handayaningrat, 2006) yaitu pengukuran yang digunakan untuk mencapai tujuan yang telah ditentukan sebelumnya. (Steers, 1984) sebagaimana dikutip oleh (Tangkilisan, 2005) dalam (Enitasari \& Hertati, 2019). Mengemukakan bahwa terdapat 5 (lima) kriteria dalam pengukuran efektivitas organisasi, yaitu produktivitas, kemampuan adaptasi atau fleksibilitas, kepuasan kerja, kemampuan berlaba, pencarian sumber daya. 
Efektivitas kelompok, organisasi, atau program dapat diketahui dengan melakukan perbandingan antara input dan output. Pada dasarnya, landasan yang digunakan untuk mengukur efektivitas kelompok, organisasi, atau program adalah keanekaragaman kelompok atau organisasi dan keinginan anggotanya, dengan begitu setiap kelompok atau organisasi mempunyai ukuran keefektifan yang berbeda-beda.

Penyandang Masalah Kesejahteraan Sosial (PMKS) adalah seseorang, keluarga atau kelompok masyarakat yang karena suatu hambatan, kesulitan, atau gangguan tidak dapat melaksanakan fungsi sosialnya sehingga tidak terpenuhi kebutuhan hidupnya baik jasmani, rohani, maupun sosial secara memadai dan wajar. Beberapa jenis PMKS yaitu: balita terlantar, anak terlantar, anak nakal, anak jalanan, dan masih banyak lagi.

Menurut Direktorat Kesejahteraan Anak, Keluarga dan Lanjut Usia, Departemen Sosial (2001), anak jalanan adalah anak yang sebagian besar waktunya dihabiskan untuk mencari nafkah atau berkeliaran di jalanan atau tempat tempat umum lainnya, usia mereka berkisar dari 6 tahun sampai 18 tahun. Adapun waktu yang dihabiskan di jalan lebih dari 4 jam dalam satu hari. Pada dasarnya anak jalanan menghabiskan waktunya di jalan demi mencari nafkah, baik dengan kerelaan hati maupun dengan paksaan orang tuanya.

Anak jalanan dapat dikatakan sebagai anak yang hidupnya kurang beruntung, terpinggirkan, tersisih, serta sebagian besar waktunya dihabiskan dengan banyak kegiatan. Salah satunya termasuk juga bekerja demi kelangsungan hidupnya. Jenis-jenis anak jalanan diantaranya Children on the street, Children of the street, Children from families of the street (Suyanto, 2010).

Telah banyak penelitian terdahulu yang meneliti tentang efektivitas program pemberdayaan anak jalanan di UPTD Kampung Anak Negeri Kota Surabaya, akan tetapi belum terdapat penelitian serupa yang melakukan identifikasi dan analisis terkait faktor-faktor baik internal maupun eksternal yang mempengaruhi efektivitas pemberdayaan anak jalanan di UPTD Kampung Anak Negeri tersebut. Dengan demikian, dapat dikatakan bahwa penelitian ini tergolong baru karena berupa peningkatan atau pun perbaikan dari penelitian-penelitian sebelumnya. Berdasarkan uraian yang dipaparkan sebelumnya, dapat dirumuskan pertanyaan penelitian yaitu bagaimana efektivitas program pelayanan kesejahteraan sosial anak jalanan di UPTD Kampung Anak Negeri Kota Surabaya dan faktor-faktor apa saja yang mempengaruhinya.

\section{Metode Penelitian}

Penelitian ini dilakukan dengan menggunakan metode penelitian kualitatif deskriptif. Metode kualitatif dipilih karena hasil temuan data yang diperoleh di lapangan merupakan hasil wawancara, observasi, dan dokumentasi yang berisikan fakta di lapangan. Lokasi penelitian adalah di UPTD Kampung Anak Negeri yang berada di Wonorejo, Rungkut, Surabaya dan Dinas Sosial Kota Surabaya yang berada di Jalan Arief Rahman Hakim No. 131-133 Surabaya. Teknik pengumpulan data utama yang 
akan digunakan berupa wawancara mendalam dan didukung dengan teknik observasi dan studi dokumen. Populasi dalam penelitian ini adalah keseluruhan anak jalanan di UPTD Kampung Anak Negeri Surabaya yang berjumlah 35 anak jalanan dan yang menjadi sampel adalah sebanyak 4 orang dari anak jalanan tersebut. Uji validitas data menggunakan teknik triangulasi. Teknik analisis data yang digunakan adalah model analisis interaktif Miles \& Huberman yang dikutip dari (Sugiyono, 2014) yang memiliki beberapa tahap yaitu: reduksi data, penyajian data dan langkah terakhir adalah penarikan kesimpulan dan verifikasi. Tahap reduksi data merupakan penyederhanaan, penggolongan, dan membuang data yang tidak perlu. Tahap kedua yaitu penyajian data merupakan kegiatan saat sekumpulan data disusun secara sistematis agar mudah dipahami. Tahap ketiga adalah penarikan kesimpulan dan verifikasi data merupakan tahap mencari hubungan, persamaan, atau perbedaan untuk ditarik kesimpulan sebagai jawaban dari permasalahan yang ada.

\section{Hasil dan Pembahasan}

Melalui UPTD Kampung Anak Negeri, program pelayanan yang diberikan kepada anak jalanan tidak hanya terkait permasalahan pendidikan, melainkan juga kebutuhan dasar dan hak-hak anak. Tujuan dari program pelayanan kesejahteraan ini adalah memulihkan kembali rasa harga diri, kepercayaan diri, dan tanggung jawab sosial, serta kemampuan anak jalanan dalam menjalankan fungsi sosial secara wajar dalam masyarakat. Berikut gambaran strategi, pengelolaan dan pelaksanaan program pelayanan kesejahteraan sosial di UPTD Kampung Anak Negeri:

\section{Strategi}

Pertama, menelusuri dan mengungkap latar belakang dari anak jalanan dengan pendataan terkait identitas anak. Kedua, melaksanakan diagnosa permasalahan dengan mengidentifikasi masalah anak jalanan berdasarkan kebutuhannya. Ketiga, menentukan langkah-langkah rehabilitasi. Keempat, menentukan dukungan pelatihan yang diperlukan. Kelima, menempatkan anak jalanan dalam proses rehabilitasi. Berdasarkan tahapan-tahapan strategi pelayanan kesejahteraan anak jalanan di atas, pihak UPTD Kampung Anak Negeri telah melaksanakan pendampingan dengan baik. UPTD telah memiliki jadwal kegiatan dan pembagian individu atau kelompok. Pelaksanaan tahapantahapan tersebut dilakukan dengan kerjasama dan koordinasi dari pihak-pihak yang berada di UPTD Kampung Anak Negeri.

\section{Pengelolaan}

Pengelola pelayanan anak jalanan di UPTD Kampung Anak Negeri ini berjumlah 3 orang PNS (Kepala UPTD, Kasubag Tata Usaha, dan Staf Administrasi), dengan dibantu 20 orang tenaga kontrak yang terdiri dari 5 orang pembina, 5 orang pendamping, tenaga keamanan 4 orang, tenaga kebersihan 3 orang, juru masak 2 orang, tenaga sopir 1 orang. Tanggung jawab atas berjalannya seluruh pelayanan sosial di UPTD dipegang oleh Kepala UPTD. Kepala Kasubag Tata Usaha bertanggung jawab 
atas terselenggaranya ketatausahaan di UPTD. Sedangkan Staf Administrasi bertugas membantu Kepala UPTD dalam urusan ketatausahaan maupun rumah tangga.

Berdasarkan hasil temuan di atas dapat diketahui bahwa pengelolaan UPTD Kampung Anak Negeri dilakukan setidaknya oleh 3 orang tenaga PNS dan dibantu oleh 20 orang tenaga kontrak. Masing-masing pengelola melaksanakan tugas dengan baik, serta melakukan koordinasi satu dengan lainnya.

\section{Pelaksanaan}

Program pelayanan kesejahteraan anak jalanan ini diselenggarakan melalui berbagai jenjang. Program ini sendiri diharapkan dapat menimbulkan keuntungan, kemanfaatan, keterampilan, dan bakat bagi anak jalanan sehingga mereka dapat berperilaku dengan normatif serta dapat mencapai kemandirian. Untuk mencapai tujuantujuan tersebut, UPTD Kampung Anak Negeri menggunakan model pelayanan pendampingan dan pembinaan. Pelayanan yang diberikan kepada anak jalanan tersebut meliputi:

Pertama, pemenuhan kebutuhan pokok yaitu pangan, sandang, dan papan. Kedua, pemenuhan kebutuhan bimbingan mental spiritual. Ketiga, pemenuhan kebutuhan bimbingan mental perilaku berorientasi pada perubahan sikap dan perilaku yang normatif yang dilakukan dalam bentuk ceramah, outdoor play, sharing, dan lainlain. Keempat, pemenuhan kebutuhan bimbingan minat keterampilan yang berupa pengenalan kegiatan wirausaha dan fasilitas program kuliah yang berbasis life skill (bimbingan jasmani, sosial, minat, dan kognitif). Bimbingan yang diberikan kepada anak jalanan tersebut seperti pelatihan handycraft, pembinaan seni, bela diri, pelatihan kewirausahaan, serta olahraga prestasi (voli, futsal, catur, tenis meja). Bimbingan kognitif juga diberikan kepada anak jalanan untuk meningkatkan aspek pengetahuan dan daya pikir guna bekal ilmu dalam mengatasi berbagai tugas kehidupannya.

Berdasarkan hasil temuan di atas, pelaksanaan pelayanan kesejahteraan bagi anak jalanan sudah berjalan dengan baik untuk pendidikan minat bakat dan edukasi yang mereka dapatkan. Anak jalanan di UPTD Kampung Anak Negeri juga mengenyam pelajaran pokok seperti Matematika, IPA, IPS, Bahasa Inggris, dan lain-lain pada pendidikan di sekoah formal dengan biaya dari UPTD. Kemudian, bagi anak-anak yang belum mengenyam pendidikan formal, pelayanan berupa bimbingan ujian kejar paket yang bekerjasama dengan instansi terkait.

\section{Efektivitas Program Pelayanan Kesejahteraan Anak Jalanan di UPTD Kampung Anak Negeri}

Efektivitas program pelayanan kesejahteraan anak jalanan di UPTD Kampung Anak Negeri Kota Surabaya berdasarkan temuan data yang kemudian dianalisis menggunakan indikator efektivitas menurut James L. Gibson adalah sebagai berikut: 


\section{Kejelasan tujuan yang hendak dicapai}

Program pelayanan kesejahteraan anak jalanan bertujuan untuk memulihkan rasa percaya diri, harga diri, dan tanggung jawab anak jalanan serta membentuk kemampuan mereka dalam menjalankan fungsi di masyarakat. Di sisi lain, tujuan tersebut didukung melalui visi UPTD Kampung Anak Negeri untuk membantu anak jalanan agar mandiri dan memiliki perilaku normatif supaya dapat melaksanakan fungsi sosialnya kepada masyarakat. Berdasarkan data yang diperoleh oleh peneliti, tujuan tersebut belum tercapai dikarenakan hambatan internal yang dimiliki oleh anak jalanan yang kurang termotivasi, malas belajar, serta belum mampu berperilaku normatif sehingga sulit untuk mematuhi aturan-aturan yang diperintahkan. Pemaparan tersebut memiliki kesesuaian dengan penelitian terdahulu yang menjadi rujukan utama panalitian ini bahwa pada pelaksanaannya UPTD Kampung Anak Negeri belum melaksanakan strategi pencapaian tujuan dengan baik sehingga tujuan pelaksanaan program belum tercapai.

\section{Kejelasan strategi pencapaian tujuan}

Strategi yang digunakan oleh UPTD Kampung Anak Negeri dalam program pelayanan kesejahteraan anak jalanan dimulai dengan penelusuran latar belakang, diagnosa permasalahan, menentukan langkah rehabilitasi, menentukan dukungan dan kebutuhan anak jalanan, serta penempatan anak jalanan dalam proses rehabilitasi. Strategi tersebut tidak hanya saat anak jalanan di dalam UPTD, akan tetapi untuk jangka panjang yaitu hingga mencapai kemandirian. Penelitian sebelumnya menyatakan bahwa tidak ada strategi memberikan modal kepada anak jalanan di UPTD yang tertarik untuk berwirausaha dan tidak ada kerjasama dengan perusahaan-perusahaan yang mempekerjakan alumni UPTD. Serta strategi mencapai tujuan hanya terbatas pada pelaksanaan kegiatan di UPTD saja dan tidak ada strategi khusus. Akan tetapi, berdasarkan informasi yang diperoleh dari data UPTD Kampung Anak Negeri, dalam kurun waktu 2 tahun terakhir terdapat kurang lebih 4 anak yang melanjutkan ke jenjang paska SMA yaitu lanjut ke jenjang kuliah, bekerja di Hotel Mercure, bekerja di UPTD Liponsos Keputih, dan di Linmas Kota Surabaya (Bledek, Syafi'i, Ketut, Dayat). Selain itu, anak jalanan juga dibekali keahlian berwirausaha seperti cuci motor, membuat ayam geprek, membuat minuman tradisional, atau keahlian service handphone. Terdapat pula banyak anak jalanan di UPTD Kampung Anak Negeri yang meraih prestasi seperti Ari yang meraih juara 1 pertandingan tinju kelas $38 \mathrm{~kg}$, Hasyim juara 1 pencak silat seSurabaya, Marfel meraih juara 3 cabang balap sepeda MTB Piala Koni Kota Surabaya, dan Luhur yang meraih juara 2 balap sepeda Trophy Ketua ISSI Jawa Tengah. Meskipun banyak prestasi yang dicapai oleh beberapa anak jalanan, permasalahan internal yang terjadi dari dalam diri anak jalanan sendiri turut menjadi penghambat efektifnya program layanan kesejahteraan ini. Berdasarkan hasil wawancara dengan salah satu pembina kognitif, terdapat beberapa anak yang tidak mendengarkan atau mengikuti bimbingan dengan baik. Hal ini membuat penerimaan program layanan kepada anak jalanan menjadi kurang efektif. 


\section{Perencanaan yang matang}

Kurikulum yang terdapat di UPTD Kampung Anak Negeri dibuat dengan mempertimbangkan kebutuhan dari anak jalanan. Program pelayanan yang direncanakan dibuat untuk jangka waktu satu tahun dan dirancang oleh tenaga pembina selaku pengajar dan pembimbing anak jalanan. Rancangan program terlebih dahulu didiskusikan bersama dengan kepala UPTD, staff, dan pendamping bersama dengan pembina. Rancangan program kemudian diberikan kepada Kepala Dinas Sosial Kota Surabaya untuk dipertimbangkan dan disetujui terlebih dahulu. Berdasarkan alur perencanaan tersebut, koordinasi antar pihak-pihak terkait program layanan kesejahteraan anak jalanan telah berjalan dengan baik dan berlangsung secara dua arah melalui diskusi dan persetujuan pihak-pihak terkait. Temuan ini sesuai dengan hasil dari rujukan utama dari penelitian ini bahwa kurikulum pendidikan di UPTD dibuat dengan banyak petimbangan dan melibatkan banyak pihak yang terkait dengan program.

\section{Penyusunan program yang tepat}

Kegiatan dan program untuk anak jalanan yang berlangsung di UPTD Kampung Anak Negeri yaitu bimbingan jasmani (voli, futsal, kerja bakti), bimbingan sosial berupa bimbingan untuk membangun komunikasi, bimbingan hidup bermasyarakat, kunjungan keluarga, bimbingan minat dan bakat (handycraft, seni musik, bela diri, kewirausahaan), dan bimbingan kognitif (pendidikan formal, calistung, persiapan ujian, pendampingan belajar/pengerjaan tugas sekolah). Dari pemaparan program-program tersebut, penyusunan program telah dipertimbangkan sesuai kebutuhan anak jalanan. Akan tetapi, kenyataan di lapangan tidak berjalan sesuai dengan program yang telah disusun sebagaimana tertulis di atas. Hal ini dikarenakan anak jalanan sebagian fokus terhadap salah satu program tetapi kurang dalam program yang lain. Apabila dibandingkan dengan hasil dari rujukan utama penelitian, pemaparan penulis di atas tidak jauh berbeda dan memiliki kesesuaian dengan hasil penelitian rujukan utama. Perbedaannya adalah bahwa hasil dalam penelitian ini menemukan bahwa anak jalanan sudah termotivasi akan tetapi hanya terfokus pada beberapa program saja sedangkan penelitian terdahulu menyatakan bahwa anak jalanan tidak memiliki motivasi mengikuti program.

\section{Tersedianya sarana dan prasarana}

Sarana dan prasarana yang terdapat di UPTD Kampung Anak Negeri dapat dikatakan sudah cukup memadai dan lengkap untuk mencapai tujuan-tujuan terkait kemandirian dan kesejahteraan anak jalanan. Di UPTD Kampung Anak Negeri terdapat berbagai fasilitas seperti ruang belajar, ruang minat bakat, ruang lukis, ruang konseling, ruang music, ruang tinju, lapangan futsal dan balap sepeda. Tidak hanya sarana dan prasarana yang diberikan UPTD Kampung Anak negeri secara kognitif, namun secara motorik juga di fasilitasi sehingga ada beberapa anak jalanan yang telah memiliki 
prestasi seperti meraih juara 1 dengan berbagai minat dan bakat yang mereka miliki.Temuan penelitian ini memiliki perbedaan dengan penelitian terdahulu yang menyatakan sarana dan prasarana masih tergolong kurang. Pada penelitian ini, peneliti menemukan bahwa sarana dan prasarana sudah cukup memadai dan ditunjukkan dengan berbagai prestasi yang diraih oleh anak jalanan di UPTD Kampung Anak Negeri.

\section{Pelaksanaan yang efektif dan efisien}

Program pelayanan anak jalanan masih belum berjalan dengan efektif dan efisien dikarenakan kurangnya kesadaran anak jalanan itu sendiri selaku elemen penting dalam program. Masih kurangnya perilaku normatif dan kurangnya kepatuhan terhadap aturan serta rasa malas dan motivasi yang rendah membuat program layanan yang diberikan kepada mereka belum berjalan dengan efektif. Hal ini berakibat pada sarana dan prasarana yang belum mampu dimanfaatkan dengan maksimal. Penelitian terdahulu menyatakan bahwa pemberdayaan anak jalanan hanya mampu menampung 35 anak dan seluruhnya laki-laki dan menjelaskan bahwa justru anak perempuan yang lebih rawan terhadap bahaya di luar. Perbedaan pembahasan antara penelitian ini dengan penelitian terdahulu adalah penelitian ini fokus terlebih dahulu pada apa yang terdapat pada UPTD Kampung Anak Negeri sedangkan penelitian terdahulu juga membahas perihal daya tampung yang hanya 35 anak dan tidak adanya tempat khusus yang menampung anak jalanan berjenis kelamin perempuan yang mana kedua hal tersebut tidak berpengaruh pada efektif atau tidaknya program yang berlangsung.

\section{Sistem pengawasan dan pengendalian yang bersifat mendidik}

Pengawasan dan pengendalian yang dilakukan oleh UPTD Kampung Anak Negeri diakukan selama 24 jam non-stop. Anak-anak jalanan yang berada di dalam UPTD didampingi oleh 5 orang pendamping yang mengawasi dan mengendalikan perilaku anak jalanan selama di dalam UPTD. Perbedaan penelitian ini dan penelitian terdahulu adalah temuan dalam penelitian ini menunjukkan bahwa meskipun telah keluar dari UPTD anak jalanan tetap diawasi dan dipantau perkembangannya bahkan mereka yang telah kuliah atau pun bekerja. Sedangkan penelitian terdahulu menyatakan bahwa tidak terdapat pengawasan lebih lanjut dan tidak terdapat informasi dari anak yang telah berada di luar atau keluar dari UPTD. Perbedaan hasil temuan dapat diterima karena rentang penelitian ini yang dilakukan pada tahun 2021 dan penelitian terdahulu pada tahun 2015 memiliki rentang yang lama. Sehingga terdapat perbedaan di UPTD Kampung Anak Negeri, akan tetapi hal tersebut justru dapat memperlihatkan bagaimana perkembangan program pemberdayaan yang terjadi di UPTD Kampung Anak Negeri Kota Surabaya tersebut.

\section{Faktor Pendukung dan Penghambat Program Pelayanan Anak Jalanan Faktor pendukung}

a. Masih terdapat banyak anak yang memiliki keinginnan belajar yang tinggi. 
b. Sarana dan prasarana dengan berbagai fasilitas untuk memenuhi kebutuhan dasar maupun kebutuhan pendidikan yang dibutuhkan oleh anak jalanan serta tenaga pembina yang turut membantu proses meningkatkan kemandirian anak jalanan.

c. Sekolah yang menerima anak jalanan untuk dapat mengenyam pendidikan.

d. Pemerintah ikut mengupayakan program pelayanan kesejahteraan yaitu dengan memberikan dana pendidikan, kebutuhan pokok, kebutuhan operasional, serta kebutuhan lainnya.

\section{Faktor penghambat}

a. Anak belum bertindak secara normatif sehingga sulit untuk dipaksa mengikuti aturan-aturan yang berlaku seperti saat mengikuti pendidikan formal di sekolah.

b. Kurangnya motivasi serta rasa malas belajar.

Kurangnya partisipasi dari keluarga mempengaruhi proses anak jalanan dalam mendapatkan pelayanan di UPTD. Karena memang sosok keluarga merupakan salah satu faktor penting yang mempengaruhi motivasi anak jalanan.

\section{Kesimpulan}

Kesimpulan dari penelitian ini adalah efektivitas program layanan kesejahteraan anak jalanan di UPTD Kampung Anak Negeri secara umum belum berjalan optimal. Hal ini dikarenakan anak belum bertindak secara normatif sehingga sulit untuk dipaksa mengikuti aturan-aturan yang berlaku seperti saat mengikuti pendidikan formal di sekolah atau mengikuti program di UPTD Kampung Anak Negeri dengan baik. Kurangnya motivasi yang dimiliki oleh anak jalanan, rasa malas belajar, serta kurangnya partisipasi dari keluarga mempengaruhi anak jalanan dalam mengikuti semua program pelayanan di UPTD.

Selain itu, kurangnya keaktifan, motivasi, serta rendahnya keinginan untuk berprestasi membuat berbagai program layanan yang diberikan kepada anak-anak jalanan tersebut berjalan tidak optimal. 
Biru Bara Nirvana Cahyadhi, Nira Zhafirah Puspitasari, Dewi Austine Britania dan Kalvin Edo Wahyudi

\section{Bibliography}

Enitasari, R., \& Hertati, D. (2019). Efektivitas Pelayanan Administrasi Kependudukan Berbasis Aplikasi Berkas Mlaku Dewe Di Kantor Kecamatan Sukodono Kabupaten Sidoarjo. Public Administration Journal, 2(5), 139. https://doi.org/10.33005/paj.v1i2.16

Handayaningrat, S. (2006). Pengantar studi administrasi.

Hasanah, B., \& Putri, L. D. (2019). Efektivitas Program Penanggulangan Anak Jalanan Berbasis Community Development di Kota Serang (Studi Pada Program Rumah Singgah). Publik (Jurnal Ilmu Administrasi), 7(2), 81-93.

Sari, D. P., \& Sumarti, T. (2017). Analisis Efektivitas Program Pemberdayaan Anak Jalanan di Rumah Singgah Tabayun Kecamatan Cibinong, Kabupaten Bogor. Jurnal Sains Komunikasi Dan Pengembangan Masyarakat [JSKPM], 1(1), 29-42. https://doi.org/10.29244/jskpm.1.1.29-42

Sari, R. F. S. (2015). Studi Deskriptif tentang Efektivitas Pemberdayaan dalam Meningkatkan Kemandirian Anak Jalanan di Unit Pelaksana Teknis Dinas (UPTD) Kampung Anak Negeri Dinas Sosial Kota Surabaya. Jurnal Kebijakan Dan Manajemen Publik, 3(1).

Steers, R. M. (1984). Organization Effectiveness: A Behavior View, diterjemahkan: Magdalena Jamin, Efektivitas Organisasi: Kaidah Perilaku, Cetakan Kedua. Erlangga, Jakarta.

Sugiyono, M. (2014). Penelitian Pendidikan Pendekatan Kuantitatif Kualitatif R\&D cet. Ke-19, Bandung: Alfabeta.

Suyanto, B. (2010). Masalah Sosial Anak. Jakarta: Prenada Media Group.

Tangkilisan, H. N. S. (2005). Manajemen publik. Grasindo.

Timur, D. S. P. J. (2019). Penyandang Masalah Kesejahteraan Sosial pada Tahun 2019. 